\title{
PEMBERDAYAAN PEREMPUAN MELALUI PEMANFAATAN MEDIA YOUTUBE DALAM MENINGKATKAN KETERAMPILAN WIRAUSAHA
}

\author{
Ipah Latipah \\ IKIP Siliwangi, Cimahi, Indonesia \\ ipahlatipah1969@gmail.com
}

Received: April, 2020; Accepted: Mei, 2020

\begin{abstract}
Women's empowerment is an effort made to build the abilities and self-concept of women through a process of awareness and education so that it can be used to improve family welfare. This study aims to determine the effect of the process of empowering women through the use of YouTube media in enhancing entrepreneurial skills. The location of the study was conducted at the NGO Bening Saguling Foundation Cihampelas, West Bandung Regency. The research method used was a descriptive qualitative method with the subject of research being a manager of empowerment and 10 housewives who became trainees. Data collection techniques through observation, interviews, and study documentation. The results showed that the use of YouTube media used in the process of empowering women could increase the creativity, interest, and motivation of women in entrepreneurship. The obstacles faced are the lack of information and communication technology facilities, busyness in taking care of the household, and the lack of confidence in the mothers in starting a business.
\end{abstract}

Keywords: Entrepreneurship, YouTube Media, Women's Empowerment

\begin{abstract}
Abstrak
Pemberdayaan perempuan merupakan suatu upaya yang dilakukan untuk membangun kemampuan dan konsep diri kaum perempuan melalui proses penyadaran dan pendidikan sehingga dapat digunakan untuk meningkatkan kesejahteraan keluarga. Penelitian ini bertujuan tujuan untuk mengetahui pengaruh proses pemberdayaan perempuan melalui pemanfaatan media YouTube dalam meningkatkan keterampilan wirausaha. Lokasi penelitian dilakukan di LSM Bening Saguling Foundation Cihampelas Kabupaten Bandung Barat. Metode penelitian yang digunakan adalah metode deskriptif kualitatif dengan subjek penelitian seorang penelola pemberdayaan dan 10 orang ibu-ibu rumah tangga yang menjadi peserta pelatihan. Teknik pengumpulan data melalui observasi, wawancara, dan studi dokumentasi. Hasil penelitian menunjukan bahwa pemanfaatan media YouTube yang digunakan dalam proses pemberdayaan perempuan dapat meningkatkan kreatifitas, minat dan motivasi para perempuan dalam kewirausahaan. Adapun kendala yang dihadapi yaitu minimnya fasilitas teknologi informasi dan komunikasi, kesibukan dalam mengurus rumah tangga, dan kurangnya rasa percaya diri ibu-ibu dalam memulai usaha.
\end{abstract}

Kata Kunci: Kewirausahaan, Media YouTube, Pemberdayaan Perempuan

How to Cite: Latipah, I. (2020). Pemberdayaan Perempuan Melalui Pemanfaatan Media Youtube dalam Meningkatkan Keterampilan Wirausaha. Comm-Edu (Community Education Journal) 3(1), 83-90. 


\section{PENDAHULUAN}

Dalam era globalisasi, peran perempuan tidak hanya sebatas mengurus dan mengatur rumah tangga serta mendidik anak di rumah. Oleh karena itu perempuan harus memiliki keterampilan dan kemandirian untuk dapat mengembangkan potensi dirinya. Selanjutnya berkaitan dengan pemberdayaan perempuan, pemerintah daerah telah melakukannya berdasarkan Program Pembangunan Nasional (PROPENAS) pada tahun 2000-2004 dalam Undang-undang Nomor 25 Tahun 2000 Bab VIII Program-Program Pembangunan butir 3 tentang kedudukan dan peran perempuan, yaitu: (1) meningkatkan kedudukan dan peran perempuan dalam kehidupan berbangsa dan bernegara melalui kebijakan nasional yang diemban oleh lembaga yang mampu memperjuangkan terwujudnya kesetaraan dan keadilan gender, (2) meningkatkan kualitas peran dan kemandirian organisasi perempuan dengan tetap mempertahankan nilai persatuan dan kesatuan, (3) meningkatkan nilai historis perjuangan kaum perempuan dalam rangka melanjutkan usaha pemberdayaan perempuan serta kesejahteraan keluarga.

Pemberdayaan perempuan menurut Roesmidi (2006: 111) “...seringkali digunakan dalam konteks kemampuan meningkatkan keadaan ekonomi (pemenuhan kebutuhan praktis) individu yang merupakan konsep yang mengandung makna perjuangan bagi mereka yang terlibat berjuangan tersebut yaitu perjuangan perempuan". Pengertian tersebut menunjukan bahwa pemberdayaan perempuan merupaja suatu upaya untuk meningkatkan keterampilan yang dapat digunakan untuk memenuhi kebutuhannya. Perempuan juga dapat memperoleh penghasilan dari potensi yang dimilikinya. Salah satu pekerjaan yang dapat dilakukan perempuanyaitu dengan berwirausaha.

Kewirausahaan merupakan kemampuan kreatif dan inovatif yang dijadikan dasar, kiat, dan sumber daya untuk mencari peluang menuju sukses. Pada intinya kewirausahaan adalah kemampuan untuk menciptakan sesuatu yang baru dan berbeda (create new and different) melalui berfikir kreatif dan bertindak inovatif untuk menciptakan peluang (Suryana, 2006: 1) Peluang berwirausagan saat ini sangat terbuka lebar, dengan perkembangan teknologi yang sangat pesat. Perkembangan media massa dalam era digital juga dirasa terhubung dengan kegiatan masyarakat dalam mencari informasi. Menurut Setiadi (2016) perkembangan penggunaan media internet sebagai komunikasi menjadi semakin pesat setelah internet mulai dapat diakses melalui telepon seluler dan bahkan kemudian muncul istilah telepon pintar (smartphone). Kecanggihan teknologi tersebut telah memudahkan kita untuk mengakses segala sesuatu yang dapat dilihat melalui internet. Internet itu sendiri terdapat media sosial yang diantaranya adalah YouTube. Pemanfaatan youtube sebagai media pembelajaran dapat digunakan setiap saat tanpa dibatasi olah ruang dan waktu dengan syarat komputer atau media presentasi terhubung dengan internet. Dengan banyak fungsinya tersebut masyarakat dapat leluasa menggunakannya untuk berbagai macam kegiatan, terutama yang menunjang kewirausahaan dalam meningkatkan taraf hidup yang lebih baik.

Berdasarkan pengamatan awal peneliti, kondisi perempuan di Desa Cihampelas didominasi oleh Ibu-Ibu rumah tangga. Kegiatan mereka sehari-hari hanya membersihkan rumah, mengurus anak-anak, dan memasak. Setelah pekerjaannya selesai, waktu luang yang ada hanya digunakan untuk berbincang-bincang bersama tetangga, menonton televisi, atau bermain smartphone. Koneksi internet yang sudah ada di Desa Cihampelas juga menjadi pendukung perkembangan media online sehingga masyarakat dengan mudah dapat mengakses berbagai informasi melalui media online. Kemampuan Ibu-Ibu dalam mengaplikasikan smartphone juga cukup baik. Beberapa Ibu-Ibu bahkan telah mengenal dan memiliki berbagai media sosial yang memungkinkan mereka memperoleh informasi lebih luas. Namun, saat ini penggunaan media online hanya sebatas untuk hiburan saja. Ibu-Ibu di Desa Cihampelas belum mampu 
memanfaatkan media online untuk menciptakan peluang usaha yang dapat meningkatkan ekonomi keluarga.

Dengan demikian, penggunaan media online sebagai sarana pemberdayaan perempuan perlu dilakukan agar Ibu-Ibu rumah tangga dapat memanfaatkan waktu luangnya secara optimal dengan meningkatkan pengetahuan, keterampilan, dan krativitasnya dalam upaya menambah penghasilan keluarga. Berdasarkan uraian tersebut, maka peneliti memfokuskan penelitian pada judul "Pemberdayaan Perempuan Melalui Pemanfaatan Media Youtube dalam Meningkatkan Keterampilan Wirausaha (Studi Kasus di LSM Bening Saguling Cihampela, Kabupaten Bandung Barat)".

\section{LANDASAN TEORI}

\section{Pemberdayaan Perempuan}

Kegiatan pemberdayaan pada penelitian ini akan difokuskan pada perempuan, yaitu upaya untuk memberikan kekuatan pada kaum perempuan. Novian (2010) pemberdayaan perempuan adalah upaya pemampuan perempuan untuk memperoleh akses dan kontrol terhadap sumber daya, ekonomi, politik, sosial, budaya, agar perempuan dapat mengatur diri dan meningkatkan rasa percaya diri untuk mampu berperan dan berpartisipasi aktif dalam memecahkan masalah, sehingga mampu membangun kemampuan dan konsep diri.

Berdasarkan pengertian tersebut, maka dapat disimpulkan bahwa pemberdayaan perempuan merupakan suatu upaya yang dilakukan untuk membangun kemampuan dan konsep diri kaum perempuan melalui proses penyadaran dan pendidikan sehingga dapat digunakan untuk meningkatkan kesejahteraan keluarga. Adapun tujuan yang ingin dicapai dari pemberdayaan menurut Sulistyani (2004: 80) adalah untuk membentuk individu dan masyarakat menjadi mandiri. Kemandirian tersebut meliputi kemandirian berpikir, bertindak dan mengendalikan apa yang mereka lakukan.

\section{Keterampilan Wirausaha}

Keterampilan adalah kemampuan untuk menggunakan akal, fikiran, ide dan kreatifitas dalam mengerjakan, mengubah ataupun membuat sesuatu menjadi lebih bermakna sehingga menghasilkan sebuah nilai dari hasil pekerjaan tersebut. Menurut Dunnette (1976) keterampilan merupakan pengetahuan yang didapatkan dan dikembangkan melalui latihan atau training dan pengalaman dengan melakukan berbagai tugas. Sedangkan kewirausahaan menurut Peter F Drucker (Kasmir, 2012: 12) mengatakan kewirausahaan merupakan kemampuan dalam menciptakan sesuatu yang baru dan berbeda. Kewirausahaan adalah ilmu, seni maupun perilaku, sifat, ciri, dan watak seseorang yang memiliki kemampuan dalam mewujudkan gagasan inovatif ke dalam dunia nyata secara kreatif.

Ada karakter-karakter yang paling dibutuhkan untuk mendukung munculnya seorang wirausaha yang berpeluang sukses tersebut, yaitu: (a) Daya gerak (drive). (b) Kemampuan berpikir (thinking ability.) (c) Kemampuan membina relasi (competency in human relation). (d) Mampu menyampaikan gagasannya (communication skills). (e) Keahlian khusus (technical knowledge). (Irianto, 2015).

\section{Media YouTube}

Nashrullah (2017: 16) mendefinisikan media sosial sebagai salah satu platform yang muncul di media siber, Karena itu, media sosial yang ada tidak jauh berbeda dengan karakteristik yang dimiliki oleh media siber. YouTube adalah situs portal video yang sering diakses para 
pengguna internet, juga mempunyai fitur berbagi video (video sharing) sehingga dapat dilihat oleh siapapun yang mengklik video tersebut. Terdapat didalamnya berbagai macam video seperti tutorial, video musik, berita dan lain-lain (Kindarto, 2008: 1). Youtube adalah sebuah situs web berbagi video yang dibuat oleh tiga mantan karyawan PayPal pada Februari 2005. Situs ini memungkinkan pengguna mengunggah, menonton, dan berbagi video (Hopskin, 2006).

\section{METODE PENELITIAN}

Metode penelitian yang digunakan yaitu dengan metode deskriptif dengan pendekatan kualitatif. Alasan peneliti menggunakan pendekatan kualitatif deskriptif, karena permasalahan yang dibahas dalam penelitian ini tidak berhubungan dengan angka-angka, akan tetapi menyangkut pendeskripsian, penguraian dan penggambaran suatu masalah yang sedang terjadi, yaitu tentang proses pemberdayaan perempuan melalui pemanfaatan media YouTube dalam meningkatkan keterampilan kewirausahaan bagi ibu-ibu rumah tangga di Desa Cihampelas. Sugiyono (2014) Penelitian kualitatif adalah suatu prosedur penelitian yang menghasilkan data deskriptif, berupa data-data tertulis atau lisan dari orang orang dan karakter yang dapat diamati sebagai objek penelitian

Lokasi penelitian ini dilakukan di LSM Bening Saguling Foundation yang beralamat di Jl. SDN Cianjur, Babakan, Cihampelas, Kec. Cihampelas, Kabupaten Bandung Barat, Jawa Barat. Subjek penelitian adalah satu orang pengelola pelatihan dan peserta pelatihan yaitu ibu-ibu rumah tangga yang berjumlah 10 orang. Sedangkan teknik pengumpulan data yang digunakan dalam penelitian ini dengan observasi, wawancara dan studi pustaka. Observasi digunakan untuk mengumpulkan data melalui pengamatan secara langsung yang dilakukan oleh peneliti mengenai proses pelaksanaan pemberdayaan perempuan. Wawancara digunakan untuk memperoleh informasi yang lebih mendalam dengan cara memberikan beberapa pertanyaan kepada subyek penelitian untuk dapat mengetahui bagaimana proses serta hasil pemberdayaan perempuan dengan pemanfaatan media YouTube. Studi dokumentasi digunakan untuk memperoleh informasi melalui referansi dan dokumen-dokumen yang sudah tersedia. Adapun langkah-langkah yang ditempuh dalam analisis data kualitatif adalah sebagai berikut; a) telaah data, b) reduksi data, c) kategorisasi, d) penafsiran data, dan3) menarik kesimpulan (Moleong, 2007).

\section{HASIL DAN PEMBAHASAN}

\section{Hasil}

Berdasarkan penelitian yang dilakukan, maka ditemukan hasil sebagai berikut:

Pada awalnya, pelaksanaan pemberdayaan perempuan dilakukan melalui kegiatan pelatihanpelatihan secara langsung yaitu pelatih memberikan dan mengajarkan keterampilan yang dimilikinya kepada ibu-ibu secara langsung. Selanjutnya, pelatihan dilakukan dengan memanfaatkan media YouTube sebagai salah satu sumber belajar. Berdasarkan hasil wawancara dengan pengelola bahwa pelatihan kewirausahaan dengan memanfaatkan media YouTube ini menggunakan video-video yang ada di YouTube sebagai sumber informasi bagi Ibu-Ibu. Hal tersebut dilakukan untuk menambah pengetahuan ibu-ibu dibidang usaha. Kondisi awal pemahaman ibu-ibu dalam menggunakan media youtube masih belum maksimal. Mereka masih belum memahami bahwa YouTube dapat memberikan berbagai informasi yang dibutuhkan termasuk usaha-usaha yang diminati. Sementara yang mereka ketahui bahwa YouTube masih digunakan untuk melihat video-video sebagai hiburan.

Pada proses pemberdayaan ibu-ibu melalui media YouTube, dilakukan dengan memberikan sosialisasi mengenai kewirausahaan dengan menggunakan media YouTube. Pelaksanaan 
dilakukan dengan mengenalkan berbagai video-video yang berkaitan dengan wirausaha. Kemudian menjelaskan cara-cara sederhana untuk mengunduh video-video tersebut dari YouTube. Ibu-ibu kemudian dapat menentukan sendiri jenis usaha yang mereka minati dan dapat mengakses video-video yang berkaitan dengan usaha tersebut. Pada proses pemberdayaan ini banyak ibu-ibu yang memiliki minat untuk berwirausaha dibidang kuliner. Sebagaimana yang disampaikan pengelola bahwa ibu-ibu banyak yang berminat diusaha makanan, mulai dari makanan ringan, kue kering, dan lain-lain. Proses selanjutnya adalah ibuibu mencoba secara berulang-ulang bagaimana mengunduh bahan-bahan untuk memulai usaha yang diinginkan. dan mempraktekannya secara langsung. Mereka kemudian bersama-sama menonton dan mencatat hal-hal yang penting dalam video tutorial dan membahasnya. Selanjutnya, mereka mencoba resep-resep tersebut dengan menambahkan kreativitas masingmasing mulai dari bentuk, warna atau varian rasanya.

Berdasarkan pengamatan peneliti, ibu-ibu mulai menguasai materi wirusaha melalui media YouTube. Mereka telah mampu mengakses dan mengunduh berbagai video-video dari YouTube, seperti resep-resep makanan ringan, kue dan lain-lain. Video tersebut dijadikan sebagai referensi untuk membuat usaha. Hasil wawancara dengan ibu-ibu mengatakan bahwa mereka merasa senang dapat melihat dan mengunduh berbagai video-video tentang usaha dari YouTube. Selain itu, mereka juga telah mengetahui cara menghasilkan produk yang bernilai jual, mengelola usaha kecil menengah, mengelola keuangan usahanya, berkolaborasi, serta cara memasarkan usahanya secara online melalui berbagai media sosial. Pemberdayaan perempuan melalui pelatihan menggunakan media YouTube dapat diterima dengan baik dan peroses pelatihanya berjalan dengan efektif dan efisien serta ibu-ibu dapat mulai memiliki penghasilan tambahan dari hasil produk yang telah di jualnya.

Ada beberapa kendala yang dihadapi pengelola dan ibu-ibu pada saat proses pelatihan kewirausahaan melalui pemanfaatan media YouTube, seperti ketersediaan akses internet, smartphone, atau komputer yang jumlahnya masih sangat terbatas. Sehingga sedikit banyak dapat menghambat pelatihan kewirausahaan dengan media YouTube ini. Selain itu dalam pelaksaan pelatihan ada ibu-ibu yang jarang datang atau tidak melanjutkan pelatihan karena kesibukannya dalam mengurus rumah, suami dan anak-anaknya. Kemudia rasa tidak percaya pada kemampuan sendiri membuat ibu-ibu banyak yang belum berani untuk memulai usaha.

\section{Pembahasan}

Proses pemberdayaan perempuan di LSM Bening Saguling dilakukan dalam bentuk pelatihanpelatihan yang diberikan untuk meningkatkan keterampilan kewirausahaan ibu-ibu rumah tangga. Sebagaimana yang diungkapkan Karwati (2017) pelatihan kewirausahaan dalam pemberdayaan perempuan adalah sebuah pembelajaran untuk meningkatkan keterampilan dan pengetahuan perempuan. Hal tersebut dilakukan agar para perempuan juga memiliki kemampuan atau keberdayaan untuk menciptakan lapangan pekerjaan.

Pemahaman awal ibu-ibu terhadap media YouTube masih sangat kurang. YouTube belum dijadikan sebagai sumber informasi yang bermanfaat. Hal ini menunjukan bahwa literasi informasi masyarakat masih rendah. Masyarkat belum mampu menggunakan teknologi informasi serta memanfaatkannya untuk meningkatkan keterampilan diri. Padahal literasi informasi menjadi faktor penting dalam membangun kapasitas diri, seperti yang dijelaskan Mulyono dan Ansori (2020) bahwa penguasaan literasi informasi menjadi salah satu syarat untuk membangun kemampuan mengelola dan memanfaatkan informasi dalam rangka memperkuat kapasistas pribadi dan pencapaian prestasi. Lebih lanjut, literasi informasi 
menjadi faktor pendukung untuk mengembangkan pembelajaran dibandingkan dengan sistem pembelajaran yang dilakukan secara konvensional. Dengan demikian, pemanfaatan media YouTube dalam proses pemberdayaan perempuan digunakan untuk meningkatkan literasi informasi masyarakat serta sebagai inovasi dalam mengembangkan pembelajaran bagi masyarakat.

Pemanfaatan YouTube sebagai sumber belajar masyarakat sangat penting terutama dalam pelatihan kewirausahaan, karena melalui YouTube masyarakat dapat belajar dan melihat atau mendengarkan secara langsung tahap-tahap memulai usaha, membuat suatu produk, dan memasarkan produk. Dengan melihat secara visual proses pelatihan akan lebih menyenangkan. Darmawati (2018) menjelaskan ada keunggulan pembelajaran dengan memanfaatkan media YouTube yaitu peserta didik tidak akan merasa bosan karena adanya media audio visual yang dapat dinikmati selama proses pembelajaran dan dapat dimanfaatkan sebagai sarana hiburan dalam pembelajaran serta sebagai saran berbagi ilmu yang sudah diperoleh.

Proses pelatihan kewirausahaan kepada ibu-ibu diawali dengan sosialisasi penggunaan media YouTube dan selanjutnya mengarahkan agar ibu-ibu dapat memiliki ide untuk membuat usaha. Dalam prosesnya, media YouTube dijadikan sebagai suber belajar dimana ibu-ibu mulai dengan mencari ilmu tentang dunia wirausaha, lalu peneliti arahkan untuk berkolaborasi dengan ibu-ibu yang lain untuk memulai usaha apa yang mudah namun menguntungkan. Hasil pelatihan menunjukkan bahwa pengetahuan dan pemahaman ibu-ibu terhadap media YouTube semakin meningkat. Berbagai informasi yang didapat dari YouTube dapat dimanfaatkan dan diolah sehingga mampu meningkatkan kreatifitas, minat, dan motivasi dalam berwirausaha. Ibu-ibu mulai menguasai materi wirausaha seperti cara menghasilkan produk yang bernilai jual, mengelola usaha kecil menengah, mengelola keuangan usahanya, berkolaborasi dengan ibu-ibu yang lain, serta cara memasarkan usahanya secara online. Pemberdayaan perempuan melalui pelatihan menggunakan media YouTube dapat diterima dengan baik dan peroses pelatihanya berjalan dengan efektif dan efisien serta ibu-ibu dapat mulai memiliki penghasilan tambahan dari hasil produk yang telah di jualnya. Sebagaimana hasil penelitian yang dilakukan oleh Kuswanti dan Oktarina (2019) yang menjelaskan bahwa dengan memanfaatkan media informasi dan teknologi komunikasi berdampak positif bagi ibu rumah tangga dalam membantu mengembangkan keterampilannya, sehingga berkembang menjadi usaha mandiri yang mampu membantu perekonomian keluarga.

Berbagai hambatan ditemui dalam proses pelaksanaan pemberdayaan perempuan ini, antara lain sebagai berikut.

a. Minimnya fasilitas teknologi informasi dan komunikasi

Fasilitas yang kurang memadai memang sangat mempengaruhi proses pelaksanaan pelatihan dengan memanfaatkan media berbasis tekonolgi informasi dan komunikasi Ketersediaan akses internet, smartphone, atau komputer jumlahnya masih sangat terbatas dapat menghambat pelatihan kewirausahaan dengan media YouTube ini.

b. Kesibukan mengurus rumah tangga

Warga belajar dalam pelatihan ini adalah ibu-ibu rumah tangga sehingga tugas utamanya adalah mengurus rumah, suami dan anak-anaknya. Sehingga dalam pelaksaan pelatihan ada ibu-ibu yang jarang datang atau tidak melanjutkan pelatihan.

c. Rasa tidak percaya diri

Tidak percaya pada kemampuan sendiri membuat ibu-ibu banyak yang belum berani untuk memulai usaha. Masih banyak dari mereka yang lebih memilih untuk ikut bekerja di usaha milik orang lain dan mendapat upah. 


\section{KESIMPULAN}

Pemberdayaan perempuan melalui pelatihan kewirausahaan dengan memanfaatkan media media YouTube merupakan salah satu upaya untuk meningkatkan pengetahuan dan keterampilan perempuan yang dapat digunakan untuk memenuhi kebutuhannya serta membantu perekonomian keluarga. Pemanfaatan media YouTube digunakan sebagai sumber belajar yang dapat merangsang kreatifitas, minat dan motivasi para perempuan dalam kewirausahaan. Hasil yang diperoleh oleh ibu-ibu rumah tangga lebih menitik beratkan pada aspek keterampilan dalam memulai dan mengembangkan usaha, meningkatkan pendapatan ibu-ibu, serta peningkatan literasi informasi masyarakat dengan memberikan pemahaman dan keterampilan dalam memanfaatkan media YouTube. Ada beberapa kendala yang dihapai selama proses pelatihan kewirausahaan dengan memanfaatkan media YouTube, antara lain; 1) minimnya fasilitas teknologi informasi dan komunikasi, 2) kesibukan dalam mengurus rumah tangga, dan 3) kurangnya rasa percaya diri.

\section{DAFTAR PUSTAKA}

Darmawati, I. A. (2018). Pemanfaatan Media Youtube Berita Pendidikan dalam Pembelajaran Keterampilan Menyimak. Seminar Nasional Bahasa, Sastra, dan Pengajarannya, 5, pp. 234-239.

Dunnette, M. D. (1976). Keterampilan Mengaktifkan Siswa. Jakarta: Kencana Prenada Media Group.

Hopskin, J. (2006, Oktober 11). Surprise! There's a third YouTube co-founder. Retrieved from USA Today: https://usatoday30.usatoday.com/tech/news/2006-10-11-youtubekarim_x.htm

Irianto, Y. B. (2015). Modul-1 Konsep-Kewirausahaan. Retrieved from http://file.upi.edu/Direkorat/FIP/JUR_ADMINISTRASI_PENDIDIKAN/1962100119 91021-YOYON_BAHTIAR_IRIANTO/Modul-1-Konsep_Kewirausaan.pdf

Karwati, L. (2017). PEMBERDAYAAN PEREMPUAN MELALUI PELATIHAN KEWIRAUSAHAAN BERBASIS POTENSI ALAM SETEMPAT. Junal Ilmiah Visi, 12(1), 45-52.

Kasmir. (2012). Kewirausahaan (Edisi Revisi). Jakarta: Raja Grafindo Persada.

Kindarto, A. (2008). Belajar Sendiri YouTube (Menjadi Mahir Tanpa Guru). Jakarta: PT Elexmedia Komputindo.

Kuswanti, A., \& Oktarina, S. (2019). PEMANFAATAN MEDIA INFORMASI DI ERA DIGITAL BAGI KEMANDIRIAN IBU RUMAH TANGGA. Suluh Pembangunan: Journal of Extention and Development, 1(1), 47-55.

Moleong, L. J. (2007). Metodologi Penelitian Kualitatif. Bandung: Remaja Rosdakarya.

Mulyono, D., \& Ansori. (2020). LITERASI INFORMASI DALAM KERANGKA PENGEMBANGAN PENDIDIKAN MASYARAKAT. Comm-Edu (Community Education Journal), 3(1), 1-6.

Nashrullah, R. (2017). Materi Pendukung Literasi Digital. Jakarta: Kementrian Pendidikan dan Kebudayaan.

Novian, B. (2010). Sekilas Tentang Pemberdayaan Perempuan. Artikel Sanggar Kegiatan Belajar Kota Pangkal Pinang.

Roesmidi, H., \& Risyanti, R. (2006). Pemberdayaan Masyarakat. Sumedang: Alqa Print Jatinangor.

Setiadi, A. (2016). Pemanfaatan Media Sosial untuk Efektifitas Komunikasi. Cakrawala: Jurnal Humaniora, 16(2). 
90 Latipah, I, Pemberdayaan Perempuan Melalui Pemanfaatan Media Youtube dalam Meningkatkan Keterampilan Wirausaha

Sulistyani, A. T. (2004). Kemitraan dan Model-Model Pemberdayaan. Yogyakarta: Gava Media.

Suryana. (2006). Kewirausahaan: Pedoman Praktis. Kiat dan Proses Menuju Sukses, Edisi Revisi. Jakarta: Salemba Empat.

Undang-Undang Republik Indonesia Nomor 25 Tahun 2000 tentang Program Pembangunan Nasional (PROPENAS) tahun 2000-2004 